\title{
PENGERTIAN LINKED LIST
}

\section{ZALMI RANDA R} 185100034

Fakultas Komputer

randa.student@umitra.ac.id

\begin{abstract}
Linked List adalah suatu struktur data linier. Berbeda dengan array yang juga merupakan struktur data linier dan tipe data komposit, linked list dibentuk secara dinamik. Pada saat awal program dijalankan elemen linked list belum data. Elemen linked list (disebut node) dibentuk sambil jalan sesuai instruksi. Apabila setiap elemen array dapat diakses secara langsung dengan menggunakan indeks, sebuah node linked list diakses dengan menggunakan mengacu pointer ke yang Awal atau kepala linked list harus diacu sebuah pointer yang biasa diberi nama head. Pointer current (disingkat curr) digunakan untuk memindahkan pengacuan kepada node tertentu.
\end{abstract}

Kata Kunci : PENGERTIAN LINKED LIST 


\section{A. PENDAHULUAN}

Linked List atau dikenal juga dengan sebutan senarai berantai adalah struktur data yang terdiri dari urutan record data dimana setiap record memiliki field yang menyimpan alamat/referensi dari record selanjutnya (dalam urutan). Elemen data yang dihubungkan dengan link pada Linked List disebut Node. Biasanya didalam suatu linked list, terdapat istilah head dan tail.

- $\quad$ Head adalah elemen yang berada pada posisi pertama dalam suatu linked list

- $\quad$ Tail adalah elemen yang berada pada posisi terakhir dalam suatu linked list

Ada beberapa macam Linked List, yaitu :

\section{Single Linked List}

Single Linked List merupakan suatu linked list yang hanya memiliki satu variabel pointer saja. Dimana pointer tersebut menunjuk ke node selanjutnya. Biasanya field pada tail menunjuk ke NULL. contoh :

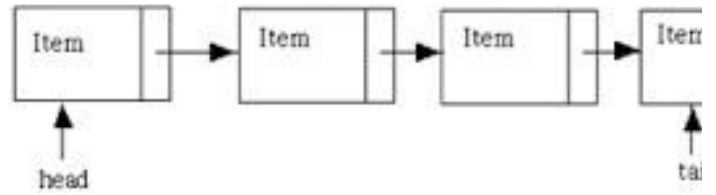

contoh codingannya :

struct Mahasiswa\{ char nama[25];

int usia; struct Mahasiswa *next;

\}$^{\star}$ head, *tail;

\section{Double Linked List}

Double Linked List merupakan suatu linked list yang memiliki dua variabel pointer yaitu pointer yang menunjuk ke node selanjutnya dan pointer yang menunjuk ke node sebelumnya. Setiap head dan tailnya juga menunjuk ke NULL. contoh :

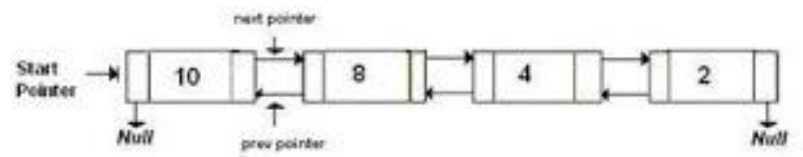

contoh codingannya :

struct Mahasiwa\{

char nama[25];

int usia;

struct Mahasiswa *next, ${ }^{*}$ prev;

\}"head, *tail;

\section{Circular Linked List}

Circular Linked List merupakan suatu linked list dimana tail (node terakhir) menunjuk ke head (node pertama). Jadi tidak ada pointer yang menunjuk NULL. Ada 2 jenis Circular Linked List, yaitu :

- $\quad$ Circular Single Linked List contoh :

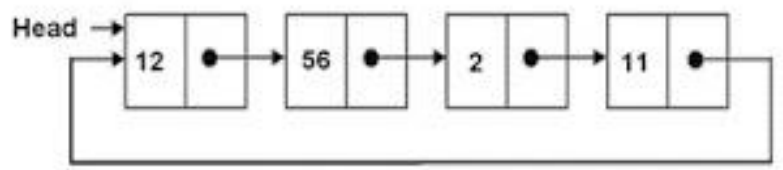


- $\quad$ Circular Double Linked List contoh :

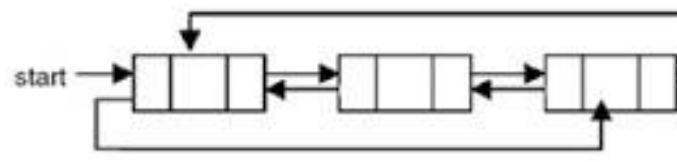

4. Multiple Linked List

Multiple Linked List merupakan suatu linked list yang memiliki lebih dar 2 buat variabel pointer. contoh ke node

berikutnya, dan juga memiliki field yang berisi data.

- Pada akhir linked list, node terakhir akan menunjuk ke NULL yang akan digunakan sebagai kondisi berhenti pada saat pembacaan isi linked list

Contoh program single linked list non circular tambah list di depan : :

\section{Non Circular linked list}

\section{Pengertian:}

Single : artinya field pointer-nya hanya satu buah saja dan satu arah. Linked List : artinya node-node tersebut saling terhubung satu sama lain.

Ilustrasinya

- Setiap node pada linked list mempunyai field yang berisi pointer clrscr();

isi_list();

clrscr(); 


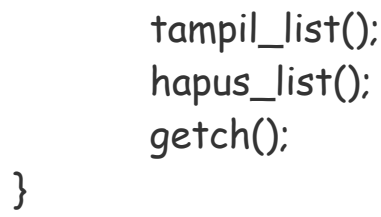

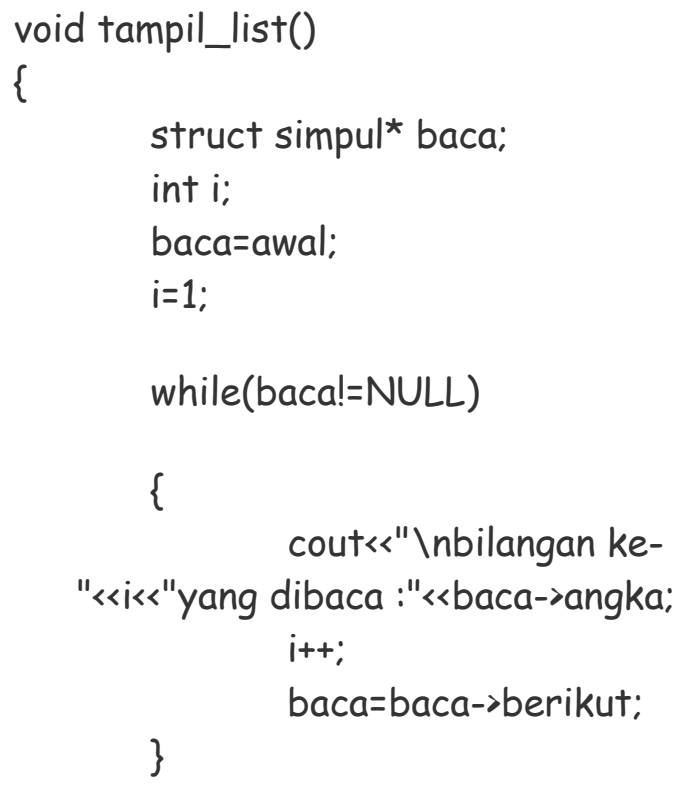




\section{B. PEMBAHASAN/STUDI KASUS}

Linked list adalah sekumpulan elemen bertipe sama, yang mempunyai keterurutan tertentu, yang setiap elemennya terdiri dari dua bagian Linked list juga merupakan suatu cara untuk menyimpan data dengan struktur sehingga dapat secara otomatis menciptakan suatu tempat baru untuk menyimpan data yangdiperlukan. Struktur ini lebih dinamis karena banyaknya elemen dengan mudah ditambah atau dikurangi, berbeda dengan array yang ukurannya tetap. berikut gambaran kecil mengenai linked list.

Ada beberapa macam Linked List, yaitu :

1. Single Linked List

2. Double Linked List

3. Operasi Pada Single

Linked List

Single Linked List

Single Linked List merupakan

suatu linked list yang hanya

memiliki satu variabel pointer

saja. Dimana pointer tersebut

menunjuk ke node selanjutnya.

Biasanya field pada tail menunjuk ke NULL.

\section{Double Linked List}

Double Linked List merupakan suatu linked list yang memiliki dua variabel pointer yaitu pointer yang menunjuk ke node selanjutnya dan pointer yang menunjuk ke node sebelumnya. Setiap head dan tailnya juga menunjuk ke NULL.

\section{Operasi Pada Single Linked}

\section{List}

1. $\quad$ Insert $=$ Istilah Insert berarti menambahkan sebuah simpul baru ke dalam suatu linked list.

2. Konstruktor $=$ Fungsi ini membuat sebuah linked list yang baru dan masih kosong.

3. IsEmpty $=$ Fungsi ini menentukan apakah linked list kosong atau tidak.

4. Find First $=$ Fungsi ini mencari elemen pert ama dari linked list

5. Find Next $=$ Fungsi ini mencari elemen sesudah elemen yang ditunjuk now.

\section{Retrieve $=$}

Fungsi ini mengambil elemen y ang ditunjuk oleh now. Elemen tersebut lalu dikembalikan oleh fungsi. 
7. Update $=$ Fungsi ini mengubah elemen yang ditunjuk oleh now dengan isi dari sesuatu.

8. Delete Now $=$ Fungsi ini menghapus elemen y ang ditunj uk oleh now. J ika yang dihapus adalah elemen pertama dari linked list (head), head akan berpindah ke elemen berikut.

\section{JELASKAN FUNGSI STACK}

\section{Pengertian Stack}

Stack adalah metode atau teknik dalam menyimpan atau mengambil data ke dan dari memori. Stack dapat diibaratkan sebuah tumpukan dalam suatu tempat yang hanya memiliki suatu pintu diatasnya. kaidah stack adalah First In Last Out atau Last In First Out (LIFO), benda yang terakhir masuk akan menjadi benda yang pertama dikeluarkan.

\section{Stack dengan Array}

Sesuai dengan sifat stack, maka pengambilan atau penghapusan elemen dalam stack harus dimulai dari elemen teratas. Ilustrasinya sebagai berikut:

Dapat dilihat dalam visualisasi stack degan array, dimna index array ke- 1 diisi oleh TV, index ke2 diisi oleh VCD dan index ke-3 diisi oleh COMBO. TOP dianggab sebagai puncak dari stack. Harus diingat bahwa banyak stack yang mungkin harus dibatasi karena alokasi memory pada array yang bersifat statis dan terbatas.

\section{ID SECURITY}

QB TD 4452377-ASP-5244107

\section{KESIMPULAN}

engertian dari list sendiri adalah koleksi dari obyekobyek dengan sifat setiap elemen memiliki penerus dan setiap elemen memiliki pendahulu.

Kesimpulan, linked-list terdiri dari 2 bagian, yaitu data dia sendiri dan alamat dari data lainnya.

Singly linked-list berarti linked-list yang setiap datanya memegang satu alamat dari data lain. (sesudah data tersebut)

Doubly linked-list berarti linked-list yang setiap datanya memegang dua alamat dari data lain. (sebelum dan sesudah data tsb) 
Circular linked-ist berarti linked-list yang head dan tailnya dihubungkan kembali, jadi data pertama berhubungan dengan data terakhir. Dalam hal ini sangat diperlukan kehati-hatian, karena bisa saja pencarian data mengakibatkan "looping forever".

\section{E. DISKUSI}

\author{
SAYA : APAKAH ARTIKEL INI \\ BERGUNA?
}

ARIA : Menurut saya artikel ini sangat berguna karena saya dapat mempelajari lebih dalam lagi tentang linked list.

\section{SAYA : APAKAH KEKURANGAN ARTIKEL INI?}

FAJAR : Menurut saya kekurangan artikel ini adalah kata-kata nya masih sedikit berantakan.

[1] A. S. Putra And O. M. Febriani, "Knowledge Management Online Application In Pdam Lampung Province," In Prosiding International Conference On Information Technology And Business (Icitb), 2018, Pp. 181-187.

[2] A. S. Putra, O. M. Febriani, And B. Bachry, "Implementasi Genetic Fuzzy System Untuk Mengidentifikasi Hasil Curian Kendaraan Bermotor Di Polda Lampung," J. Sist. Inf. Dan Manaj. Basis Data, Vol. 1, No. 1, Pp. 21-30, 2018.

[3] O. M. Febriani And A. S. Putra, "Sistem Informasi Monitoring
Inventori Barang Pada Balai Riset Standardisasi Industri Bandar Lampung," J. Inform., Vol. 13, No. 1, Pp. 90-98, 2014.

[4] Putra, Arie Setya. "2018 Artikel Struktur Data, Audit Dan Jaringan Komputer." (2018).

[5] Putra, A. S. (2018, July 17). Paperplain Fundamental Create Application With Borland Delphi 7.0 University Of Mitra Indonesia. Retrieved From Osf.Io/Pbrn9.

\section{F. REFERENCE(Based APA )}

Putra, A. S., Aryanti, D. R., \& Hartati, I. (2018, November). Metode SAW (Simple Additive Weighting) sebagai Sistem Pendukung Keputusan Guru Berprestasi (Studi Kasus: SMK Global Surya). In Prosiding Seminar Nasional Darmajaya (Vol. 1, No. 1, pp. 85-97).

Sari, D. P., Febriani, O. M., \& Putra, A. S. (2018, November). Perancangan Sistem Informasi SDM Berprestasi pada SD Global Surya. In Prosiding Seminar Nasional Darmajaya (Vol. 1, No. 1, pp. 289-294).

Putra, A. S. (2018). Paperplain: Execution Fundamental Create Application With Borland Delphi 7.0 University Of Mitra Indonesia. 
Putra, A. S., Sukri, H., \& Zuhri, K. Sistem Monitoring Realtime Jaringan Irigasi Desa (JIDES) Dengan Konsep Jaringan Sensor Nirkabel. IJEIS (Indonesian Journal of Electronics and Instrumentation Systems), 8(2), 221232.

Darmawan, A., Yuliawati, D., Marcella, O., \& Firmandala, R. (2016). Sistem Absensi dan Pelaporan Berbasis Fingerprint dan SMS Gateway. EXPLORE, 7(1).

Febriani, O. M., Wahyuni, T., \& Yusuf, S. (2017). DESIGN OF WEBSITE-BASED INFORMATION SYSTEM FOR EDOCUMENT ADMINISTRASI IN THE COMMUNITY SERVICE UNIT (A Case Study at Rajabasa District). INTERNATIONAL JOURNAL OF COMPUTERS \& TECHNOLOGY, 16(7), 7010-7020.

Febriani, O. M., \& Wahyuni, T. (2017, October). PERANCANGAN SISTEM E-DOCUMENT ADMINISTRASI LOGBOOK PENELITIAN PADA UNIT LAYANAN DI BANDAR LAMPUNG. In Prosiding Seminar Nasional Darmajaya (Vol. 1, No. 1, pp. 187-194).

Febriani, O. M., \& Permadi, A. B. (2017). Implementasi Sistem Aplikasi Data Bimbingan dan Pelanggaran Siswa pada Sekolah Menengah Atas di Lampung Tengah dengan Metode Analisis dan Desain Sistem Terdistribusi (SSAD). EXPERT, 7(1).

Febriani, O. M., \& Ambarwati, L. (2015). PERANCANGAN APLIKASI
PENGOLAHAN DATA PENJUALAN UKM KELANTING KHAS TELO DESA SIDOHARJO KECAMATAN JATI AGUNG KABUPATEN LAMPUNG SELATAN. Jurnal Teknologi Informasi dan Bisnis Pengabdian Masyarakat Darmajaya, 1(1), 77-95.

Febriani, O. M. (2015). Rancang Bangun Aplikasi Ecommercemenggunakan Freewebstore pada UKM Kelanting di Desa Sidoharjo Lampung Selatan. Prosiding Sembistek 2014, 1(02), 446-458. 